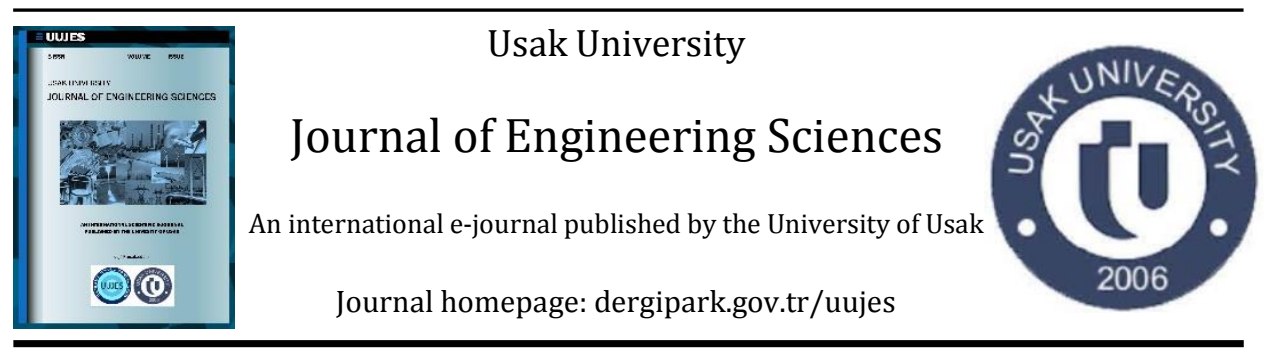

Review article

\title{
ASSESSMENT OF NOISE PROBLEM IN NONWOVEN INDUSTRY
}

\author{
Aysel Buzak1, Gizem Celep ${ }^{2 *}$ \\ ${ }^{1}$ Department of Occupational Health and Safety, Graduate Education Institute, Usak University, Usak, Turkey \\ ${ }^{2}$ Department of Occupational Health and Safety, Faculty of Health Sciences, Usak University, Usak, Turkey \\ Received:6 May $2021 \quad$ Revised: 18 May $2021 \quad$ Accepted:19 May $2021 \quad$ Online available: 30 June 2021 \\ Handling Editor Mustafa Ali Ersöz
}

\begin{abstract}
The textile industry is a constantly developing sector from the past to the present. Since the machines used in textile production are large machines and working at high speeds, they emit significant noise. Beside the health problems related to hearing, employees exposed to noise also suffer from problems such as insomnia, distractibility, and nervousness. Moreover, a high level of noise in the environment, especially in jobs that require intense attention, leads to work accident. Therefore, noise control in textile sector is very crucial. There are several control methods for reducing noise in workplaces. These methods are noise control at the source, in the path, and at the receiver. Engineering methods that control the noise at the source are about making changes in machinery and processes. In this study general knowledge about noise is given. The noise problem in the nonwoven sector and the measures that can be taken against noise are presented.
\end{abstract}

Keywords: Nonwovens; textile; noise; occupational safety; engineering methods.

(C)2021 Usak University all rights reserved.

\section{Introduction}

As a result acceleration of technological developments, the usage areas of textile products have increased. Textile fabrics, not only meet people's clothing demands, but also used in every field from construction to food sector. The relationship between raw material and end product has also changed with developments in technology. One of the most important developments in the textile sector is the advance of the technical textile field with the use of technical products in the industrial field. The high level of technical functions of the end products has greatly expanded the usage areas of textile products $[1,2]$.

Weaving, knitting and non-woven are three important surface forming techniques in the textile industry. While in weaving and knitting fabrics are produced by yarns, nonwoven

*Corresponding author: Gizem Celep

E-mail: gizem.celep@usak.edu.tr (ORCID ID: 0000-0001-9618-6708)

DOI: $10.47137 /$ uujes.934014

(C)2021 Usak University all rights reserved. 
fabrics are made directly from fibers. Since the surface is formed directly from fibers in nonwoven production, the production process is shorter and the production efficiency is higher compared to weaving and knitting techniques [3].

Today, as a result of the changing life standards and developing technology, the demand for nonwovens and disposable products is increasing rapidly. The durable and porous structures of the nonwoven products have increased their usage areas in daily life and industry. Nonwoven products can be classified into two groups as disposable and longlasting products. Refreshing wipes, cleaning wipes, diapers, overalls are disposable products. Usage areas of nonwovens change according to their properties. They are used in many fields such as automotives, filtration, medical textiles, construction, agriculture, and geotextiles. Production parameters and raw material selection change according to the properties expected from the final product in nonwovens production. The porosity, water repellency, strength, air permeability, heat insulation, sound insulation and antibacterial properties of nonwoven surfaces are affected by fiber type, fiber length, web density, weight, etc. [4-6].

Along with the technological advances, new methods are also being developed in the nonwoven fabric sector and the sector is growing rapidly. Hazards and risks are increasing day by day in constantly developing textile and nonwoven sectors. As each sector has unique hazards and risks, the textile sector also includes many risk factors in terms of occupational health and safety. Due to the high level noise created by the machines used in textile sector, health problems such as noise-induced hearing loss, tinnitus, nervousness, and distraction may occur in employees [7-9]. In this study, the noise problem that employees are exposed to in the workplaces and the precautions that can be taken against noise in the nonwoven sector are mentioned.

\section{Nonwoven Manufacturing}

In the production of nonwoven fabrics, staple or filament, natural or synthetic fibers are preferred. Fibers such as polypropylene, polyester, viscose, cotton, and their mixtures are used as raw materials. The properties of the fibrous web affect the physical properties of the final product. Different production methods can be selected according to the fiber fineness, fiber length, crimp, tensile properties and the performance characteristics expected from the products. Apart from weaving and knitting techniques, nonwoven production method involves three stages. These are web formation, web bonding and the finishing processes in which various functional properties are given to the nonwovens (Fig. 1). Nonwoven production begins with the arrangement of the fibers in a web. The fibers can be staple fibers or filaments extruded from melted polymer. In case of using staple fibers as raw material, primarily the fibers are opened, cleaned, and mixed before the web forming stage. After the preparation process is completed, fibers are placed in a web structure. The produced webs are folded in order to bring them to the desired weight [10, 11]. There are three web forming processes: dry laid, wet laid, and melt spun. Staple fibers are used in wet and dry laying technology, while filament fibers are used in filament laying technology. Web forming and bonding processes, which are the main stages in production, are carried out with different techniques and machines. The dry laid technologies are carding and air laying process. Carding is a mechanical process and fibres are 'opened' and blended and then fibers are combed into a web by a carding machine, which is a rotating drum or series of drums covered by card wire. The web structure produced by carding machine is transferred to folding machine $[11,12]$. The wet laying method is similar to conventional papermaking processes. In this process, fibers are suspended in water and parallelized. In order to create the web structure, the water is removed from the fibers and the web layer is passed through the rollers and dried. Thus the fibers are connected to each 
other. In filament laying technology, web structure is created directly from filament fibers. Fiber webs can be bonded in a variety of different ways such as thermal, mechanical and chemical bonding. Finishing is the last process performed on the web $[10,13]$. Consumers' expectations can be met by enhance the available properties of the fabric with the finishing processes.
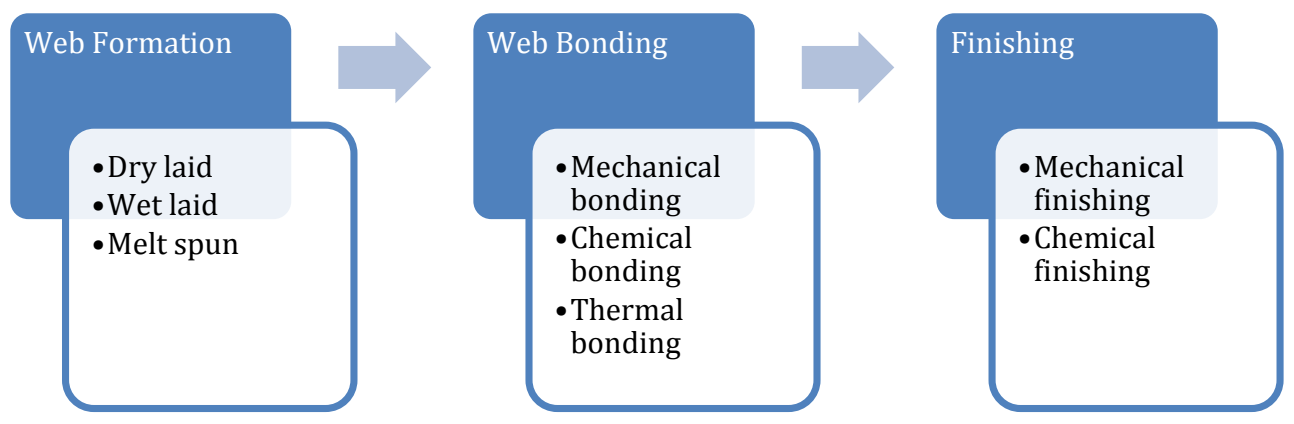

Fig. 1 Nonwoven production stages

\section{Occupational Health and Safety}

Health and safety are two phenomenons that are mutually related and complementary to each other. From legal, moral, and economic points of view, occupational safety and health has become an important subject [14].

Occupational health and safety is a multidisciplinary science that aims to make working conditions safer for employees and to prevent work accidents and occupational diseases at workplaces. The World Health Organization (WHO) and the International Labour Organization (ILO) emphasize that while there is a decrease in occupational accidents and diseases in industrialized countries, the opposite is observed in developing countries [15]. The primary purpose of occupational health and safety is to provide a healthy and safe working environment. On the other hand, factories can also have negative effects on the environment. In this respect, occupational health and safety practices are also important in terms of protecting the environment [16].

\section{Noise}

Noise is commonly defined as unwanted and unpleasant sounds that cause disturbing effects on the people. Although sound is an important and valuable part of daily life, when it turns into noise, it can negatively affect our mental and physical health. Sound pressure levels occurring in various environments and processes are shown in Table 1. In almost all workplaces, noise occurs as a result of the operations of various machines and tools, and the movements of different parts. Therefore, one of the most frequently encountered problems in working life is noise. Noise is a subjective concept that negatively affects human comfort [17]. Although there are different approaches in evaluating the sound level, the most known measurement is the sound pressure level measurement. The sound pressure level is expressed in decibels $(\mathrm{dB})$, which is a logarithmic quantity. On the other hand, dBA is a unit of sound especially emphasized by the middle and high frequencies to which the human ear is most sensitive. The dBA unit used in noise control is also associated with the subjective evaluation of sound volume [18]. 
Table 1 Sound sources and levels [16, 19-21]

\begin{tabular}{l|l|l|l}
\hline Noise type & $\begin{array}{l}\text { Sound pressure } \\
\text { level (dB) }\end{array}$ & Subjective & $\begin{array}{l}\text { Textile related/Textile } \\
\text { unrelated }\end{array}$ \\
\hline $\begin{array}{l}\text { Threshold of hearing } \\
\text { Whisper }\end{array}$ & 0 & $\begin{array}{l}\text { Very low } \\
\text { Very low } \\
\text { Low }\end{array}$ & Textile unrelated \\
Library & 20 & Middle & \\
Office noise & 30 & High & \\
$\begin{array}{l}\text { Sound of typewriter } \\
\text { keys }\end{array}$ & 70 & High & \\
\hline Average engine noise, & $60-80$ & Very high & \\
Discomfort & $80-85$ & Very high & \\
Blowroom & $80-85$ & Very high & \\
Carding machine & $80-85$ & Very high & Textile related \\
Draw frame machine & $85-93$ & Very high & \\
Roving frame & 95 & Very high & \\
Ring spinning machine & 95 & & \\
Gripper shuttle loom & & Damaging & \\
\hline Air hammer & 125 & Damaging & Textile unrelated \\
Jet engine & $130-140$ & & \\
\hline
\end{tabular}

Daily noise exposure limit and action levels stated in Regulation on Protection of Employees from Noise Related Risks are given in Table 2.

Table 2 Exposure limit values and action values [22]

\begin{tabular}{lcc}
\hline & $\begin{array}{c}\text { Daily noise exposure level } \\
\text { (LEX,8h) (dBA) }\end{array}$ & $\begin{array}{c}\text { Peak sound } \\
\text { pressure (Pa) }\end{array}$ \\
\hline Lower exposure action value & 80 & 112 \\
Higher exposure action value & 85 & 140 \\
Exposure limit value & 87 & 200 \\
\hline
\end{tabular}

Noise has many negative effects on human health. Among these, the first health problem comes into mind is hearing loss. It is known that sound pressure values of 85 decibels and above cause hearing loss. The negative effects of noise are not limited to hearing loss. At the end of the working day, insomnia, distractibility, and nervousness are observed in people working at noisy environments. Another important health hazard of noise is the risk of accident. Employees' concentration degreases due to noise, and their attention is reduced. People may not notice warnings on time, and this creates a risk for accidents [16, 23-26]. For these reasons, periodic noise measurements should be made in workplaces that require noisy operation. Measuring the ambient noise levels and the noise risks of the employees is the most important part of the noise control program in the workplace. In order to control noise effectively, measurements should be made and evaluated in accordance with standards.

The noise characteristic plays a significant role in the selection of noise measuring device. Sound level meters are used for measurements of regular noise, while dosimeter is preferred for measurements of irregular and impact noise. The most common instruments used for measuring noise are sound level meter (SLM), integrating sound level meter 
(ISLM), and the noise dosimeter. The SLM comprise of a microphone, electronic circuits and a reading display. The microphone detects the small air pressure variations related sound and changes them into electrical signals. These signals are processed by the electronic circuit. ISLM is similar to the dosimeter and determines equivalent sound levels throughout the measurement period. The major difference is that ISLM does not measure personal exposure. The noise dosimeter is a small, lightweight device worn by the employee. It is useful in processes where noise often changes in intensity and the person is changed place [27].

\section{Noise Problem in Nonwovens Industry}

The competitiveness and working environment in the textile sector also bring about work accidents and occupational diseases. Noise, one of the occupational health and safety hazards, is an important risk factor for employees in textile industry. Employees working in textile and nonwovens sector are exposed to different levels of noise in the production processes. Employees are exposed to noise when working with machines used in the textile industry, working with air conditioning ventilation and electrical installations [28]. The types, and technology of machines used, the factory buildings size are more important factors that determine the sound level. When the sound pressure level values emitted by weaving machines are between 78.3 and $100.8 \mathrm{~dB}$, in spinning machines these values are between 74.7 and $90.3 \mathrm{~dB}$. It has been determined that the sound pressure level emitted by weaving machines varies between 87.7 and $98.1 \mathrm{~dB}$ and in spinning machines between 81.2 and $88.8 \mathrm{~dB}$ at a frequency of $4,000 \mathrm{~Hz}$ where the human ear is the most sensitive. While the equivalent sound level values emitted by weaving machines ranged from 97.1 to $105.5 \mathrm{dBA}$, these values were determined to be between 89.7 and $93.9 \mathrm{dBA}$ for spinning machines [29].

Blow room machines, carding machines, needle punch machines, and even the voices coming out of the ventilation systems are sources of noise in nonwoven factories. The noise level in the nonwoven preparation processes is lower than the sections where the main production line is located. The noise level in area where carding machines are located exceeds $85 \mathrm{dBA}$, which is the highest exposure action value. The most commonly used web bonding method among mechanical bonding techniques is needle punching. At needle punching unit the sound pressure level exceeds $85 \mathrm{dBA}$. The high speeds machines used in the production of nonwovens and the use of high pressure air are the most important factors that increase the noise level. In nonwoven factories, the risk of hearing loss is high with high noise levels in long-term work without the use of suitable hearing protectors [3].

\section{Noise Control}

Noise-induced hearing loss is an occupational disease, and technical, medical and organizational measures should be taken to prevent these diseases. The noise caused by the machines in nonwoven factories creates a serious problem for the employees at workplace. There are several methods to control and reduce noise level in workplaces. These methods are noise control at the source, noise control in the path and noise control at the receiver (Fig. 2). 


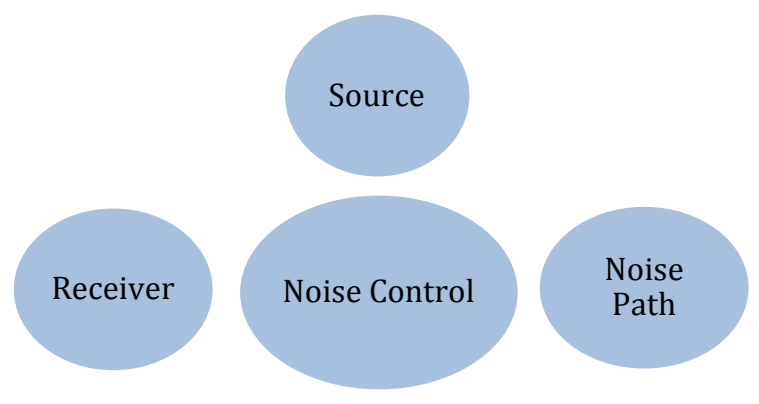

Fig. 2 Noise control methods

The most effective of these are noise control at the source and engineering controls. Engineering controls are about making changes to machine and processes. Using machines that make less noise, noise control with planning and maintenance, vibration isolation, and changes in operating conditions are among the measures to be taken for noise control at the source [30]. Noise is generated by vibrating sources. If vibration can be eliminated or reduced, noise can also be eliminated or reduced. It is also an effective process to insulate the vibrating parts of the noise source. If the noise cannot be eliminated or reduced at the source, measures should be taken in the propagation path of the noise. At this point, the distances of the machines to each other can be adjusted and surfaces such as walls, floors, and ceilings can be covered with sound absorbing or insulating materials. In workplaces where noise exposure cannot be prevented by these methods, hearing protectors should be given to prevent or minimize the risk. If the noise level exceeds $85 \mathrm{~dB}$, employees should definitely use hearing protectors. In addition, employees should be given rotational work to reduce their exposure to noise in the workplace. Audiometry tests should be performed for employees in workplaces with high noise levels during employment and periodic examinations [31-34].

\section{Conclusion and Suggestions}

Noise is an important risk factor for employees. The noise negatively affects human health. The noise in the workplace can cause serious damages to the functioning of the work, productivity, and workers' health. Noise-induced hearing disorder is an irreversible occupational hazard. Precautions can be taken against noise by reducing the number or impact of sources that generate noise in working or living areas. Before this, it is necessary to determine the noise level in the environment by measuring the workplace environment. In this way, it can be determined which machine or which process generates more noise and which employees are affected more. In order to reduce noise exposure in the textile and nonwoven sector, the machines used in the workplaces should be replaced with machines that emit less noise. Engineering measures should be taken in enterprises where this is not possible and personal protective equipment should be used as a last resort. Creating quiet areas in nonwoven factory where employees can get away from the noise will reduce the average daily noise exposure and alleviate the effects of noise. 


\section{References}

1. Kumar RS. Textiles for industrial applications. CRC Press; 2013.

2. Kaddar TR. Future vision for development in textile science and engineering. J Textile Sci Eng, 2018; 8(381): 1-2.

3. Nefes A. Dokusuz kumaş üretimi yapan işletmelerde risklerin değerlendirilmesi. İş Sağlığı ve Güvenliği Uzmanlık Tezi. 2016.

4. Thangadurai $\mathrm{K}$, Thilagavathi $\mathrm{G}$ and Bhattacharyya A. Characterization of needlepunched nonwoven fabrics for industrial air filter application. The Journal of the Textile Institute, 2014; 105(12): 1319-1326.

5. Payen J, Vroman P, Lewandowski M, Perwuelz A, Calle-Chazelet S and Thomas D. Influence of fiber diameter, fiber combinations and solid volume fraction on air filtration properties in nonwovens. Textile Research Journal, 2012; 82(19): 19481959.

6. Shahani F, Soltani P and Zarrebini M. The analysis of acoustic characteristics and sound absorption coefficient of needle punched nonwoven fabrics. Journal of Engineered Fibers and Fabrics, 2014; 9(2): 84-92.

7. Belachew A and Berhane Y. Noise-induced hearing loss among textile workers. The Ethiopian Journal of Health Development, 1999; 13(2).

8. Talukdar M K. Noise pollution and its control in textile industry. Indian Journal of Fibre \& Textile Research, 2001; 26: 44-49.

9. Jayawardana T S S, Perera M Y A and Wijesena G H D. Analysis and control of noise in a textile factory. International Journal of Scientific and Research Publications, 2014; 4(12): 1-7.

10. Russell S J. Handbook of Nonwovens. Woodhead Publishing Limited and CRC Press, England, 2007.

11. Allen Jr H C. Preparing cotton, web forming and bonding methods for cotton nonwovens. In Proceedings, 1998.

12. Albrecht $\mathrm{W}$, Fuchs $\mathrm{H}$ and Kittelmann W. Nonwoven fabrics: raw materials, manufacture, applications, characteristics, testing processes. John Wiley \& Sons, 2006.

13. http://www.edana.org/discover-nonwovens/what-are nonwovens

14. Friend M A and Kohn J P. Fundamentals of occupational safety and health. Rowman \& Littlefield, 2018.

15. Benjamin O. Alli. Fundamental Principles of Occupational Health and Safety, 2008.

16. Bilir N. İş Sağlığı ve Güvenliği, Güneş Tıp Kitabevi, 2016.

17. Nassiri P, Monazam M, Dehaghi B F, Abadi L I G, Zakerian S A and Azam K. The Effect of Noise on Human Performance: A Clinical Trial. Int J Occup Environ Med., 2013; 4(2): 87-95.

18. Çevresel Gürültünün Değerlendirilmesi ve Yönetimi Yönetmeliği, 2010. https://www.mevzuat.gov.tr/mevzuat?MevzuatNo=14012\&MevzuatTur=7\&Me vzuatTertip $=5$

19. Sağbaș A, Kahraman F, Eşme U and Özbek A. Tekstil işletmelerinde gürültü ve gürültünün azaltılmasında mühendislik önlemler. Çukurova Üniversitesi Mühendislik-Mimarlık Fakültesi Dergisi, 2008; 23(1): 181-187.

20. Çevresel gürültü ölçüm ve değerlendirme kılavuzu. Çevre ve Orman Bakanlığı, Çevre Yönetimi Genel Müdürlüğü, Hava Yönetimi Dairesi Başkanlığı, Ankara, 2011.

21. Yılmaz F, Celep G, Tetik G. Çeșitli tekstil fabrikalarındaki gürültü seviyeleri, ölçümü ve korunma yöntemleri. 9th International Congress on Occupational Health and Safety; 2018 May 6-9; Türkiye, İstanbul.

22. Çalıșanların Gürültü ile İlgili Risklerden Korunmalarına Dair Yönetmelik, 2013. https://www.resmigazete.gov.tr/eskiler/2013/07/20130728-11.htm 
23. Jariwala H J, Syed H S, Pandya M J and Gajera, Y M. Noise Pollution \& Human Health: A Review. Indoor and Built Environment, 2017; 1-4.

24. Jhanwar D. Noise Pollution: A Review. Journal of Environment Pollution and Human Health, 2016; 4(3): 72-77.

25. Hsu T, Ryherd E, Waye K P and Ackerman J. Noise pollution in hospitals: impact on patients. JCOM, 2012; 19(7): 301-9.

26. Toppila E, Pyykkö I and Pääkkönen R. Evaluation of the increased accident risk from workplace noise. International journal of occupational safety and ergonomics, 2009; 15(2):155-162.

27. Canadian Centre for Occupational Health and Safety (CCOHS), Noise Measurement of Workplace Noise, https://www.ccohs.ca/oshanswers/phys_agents/noise_measurement.html

28. Tekstil Sektöründe İş Sağlı̆̆ı Gözetimi Rehberi, İş Sağlığı ve Güvenliği Genel Müdürlüğü.

29. Ece F, Sümer SK, Sabancl A. Tekstil fabrikalarinda gürültü düzeyi ve etkileri. Mesleki Sağlık ve Güvenlik Dergisi (MSG), 2015; 4(15): 30-39.

30. Şahin, E. Gürültü kontrol yöntemleri-bir uygulama. Gazi Üniversitesi Mühendislik Mimarlık Fakültesi Dergisi, 2003; 18(4): 67-80.

31. Hansen C H and Bies D A. Engineering noise control. London: Spon, 1995.

32. Uğurlu, F. Tekstil Sektöründe İș Sağlığı ve Güvenliği, ÇSGB, 2011.

33. Meslek Hastalıkları ve İş ile İlgili Hastalıklar Tanı Rehberi.

34. Çalışma Yaşamında Sağlık Gözetimi Rehberi, 2012. 